COMPETITOR: Jurnal Pendidikan Kepelatihan Olahraga

Volume 13 Number 2 Year 2021

e-ISSN: 2657-0734 \& p-ISSN: 2085-5389

This work is licensed under a Creative Commons Attribution 4.0 International License

\title{
Evaluation of Rowing Sport Coaching Program in PODSI Barito Kuala Regency
}

\author{
Supian Hadi ${ }^{1^{*}}$, Rahmadi $^{2}$, Mashud $^{3}$ \\ 1,2,3 Magister Keguruan Olahraga/Universitas Lambung Mangkurat Banjarmasin/ \\ South Borneo/Indonesia \\ ${ }^{1,2,3}$ Street. H. Hasan Basri, Kayu Tangi, Banjarmasin City, South Borneo \\ ${ }^{1}$ supianhadi771@gmail.com, ${ }^{2}$ rahmadi@ulm.ac.id, ${ }^{3}$ mashud@ulm.ac.id
}

Received: April 12, 2021; Reviewed: May 8, 2021; Accepted: May 20, 2021; Published: June 19, 2021

\begin{abstract}
The research objective was to determine whether the coaching program at PODSI Barito Kuala Regency was effective and following what was made in the coaching program. This type of research is an evaluation of the Countenance Stake model. Data collection was done by filling out questionnaires, interviews, observation and documentation. The results of the research with the evaluation of the Contenance Stake model from filling out the questionnaire showed that the antecedent component was obtained in the medium category, the transaction component was in the medium category, and the outcome component was in the moderate category, the results of interviews, observation and documentation of PODSI Barito Kuala Regency, in collaboration with the Provincial Dispora and Kemenpora in the form of PPLP and $P P L P D$, do not have a licensed rowing coaching coach, do not have a licensed referee, the facilities are still lacking. The program research recommendation is continued to need to increase the capacity of coaches, referees and improve facilities, infrastructure and special canals for rowing so that they become a medium for recreation for athletes and the implementation of rowing championships in the Barito Kuala district.
\end{abstract}

Keywords: Evaluation; Coaching; Sports; Rowing.

\section{INTRODUCTION}

The rapid development of the times has an impact on the knowledge and awareness of the Indonesian people about the importance of exercising which is also increasing. Developments in the world of sports are not only in recreational sports and educational sports but also in achievement sports activities, this is evidenced by the increasing number of fitness centres and sports associations throughout Indonesia and especially in the regions.

Rowing is one of the most popular water sports in Indonesia, so this sport is included in the category of recreational or achievement sports. Rowing is a very complex 
Evaluation of Rowing Sport Coaching Program in PODSI Barito Kuala Regency

Supian Hadi $^{1^{*}}$, Rahmadi ${ }^{2}$, Mashud ${ }^{3}$

supianhadi771@gmail.com

sport. The rowing sport that is developing in Indonesia is a combination of several sports, namely Rowing, Canoeing, and Traditional Boat Race in the world order of international sports. The three sports have their international parent organizations for rowing under the federation international societies de Aviron (FISA), for canoeing under the International Canoeing Federation (ICF) and traditional boat races or dragon boats under the international dragon boat federation (IDBF).

In Indonesia, the three sports (Rowing, Canoe and dragon boat) are under the same parent organization, namely: Persatuan Olahraga Dayung Seluruh Indonesia (PODSI). In the province of South Kalimantan, especially Barito Kuala Regency is an area that is mostly water areas, rowing is a mainstay sport for regional events until the national event rowing athletes from Barito Kuala Regency have always been the General Champion at three Provincial Sports Week events, namely the Sports Week Province in 2010 in Kota Baru, Provincial Sports Week in 2013 in Banjar Regency and the last Provincial Sports Week in 2017 in Tabalong Regency, but from getting medals in the last three Provincial Sports Weeks PODSI, Barito Kuala Regency, it has always been difficult to get a gold medal, especially in kayak number one both from the men's category and the women's category, as well as canoeing number one, at the 2017 Provincial Sports Week in Tabalong Regency, for the men's kayak the gold medal was won by Hulu Sungai Utara district and for the women's kayak the gold medal was won by rowing athletes from the city of Banjarmasin, there is also from the canoe number one male gold medal was also obtained by athletes from the North Hulu Sungai district.

Barito Kuala District athletes are also part of every event Pekan Olahraga Nasional (PON) both from the canoe, kayak and dragon boat numbers, in the rowing sport there are several race numbers including canoe 1 male and female canoe 2 male, rowing single scull, 2 min, 4 min male and female, kayak 1 male and female, kayak 2 sons and daughters, kayaks 4 sons and daughters and a dragon boat. Dragon boat rowing athletes totalling 22 people or 12 people consisting of 20 or 10 rowers, 1 drummer in front, and 1 driver behind also competed in the male and female categories.

Persatuan Olahraga Dayung Seluruh Indonesia (PODSI) is the parent organization that covers rowing sports throughout Indonesia. Like other sports, rowing is influenced by many factors as a determinant of the achievement of achievement. Rowing is a sport that is carried out in waters using equipment in the form of paddle leaves and boats, both kayaks, canoes and dragon boats. To become a good rower and achieve maximum results, regular and scheduled training and coaching are needed, so that the athlete has 
Evaluation of Rowing Sport Coaching Program in PODSI Barito Kuala Regency

Supian Hadi $^{1^{*}}$, Rahmadi ${ }^{2}$, Mashud ${ }^{3}$

supianhadi771@gmail.com

good physical abilities, good technical skills, application of varied coaching strategies and techniques as well as strong and tough mental mastery and control. in the face of competition. (Zulmi, 2012 p.2).

The training program is a set of training activities made by the coach to improve the athlete's ability. The form of the training program is in the form of daily, weekly, monthly, and yearly so that it can be carried out by athletes in the form of training load and exercise intensity. According to (Dermawan, 2018 p.3)" Training planning is an important thing that must be done by a coach. As with most coaches, training must be well organized and planned to ensure the achievement of the training objectives. According to (Oemar, 2018 p.1) The training program is an exercise system created by a coach to improve the athlete's ability. The form of the training program is in the form of daily, weekly, monthly, to yearly depending on the athlete's preparation time for an event."

To support an expected achievement, an evaluation is needed which aims to identify and parse the weaknesses and shortcomings of the previous program. So that we get a solution to make the next program better. According to (Wani1, 2018 p.3) A systematic and continuous, planned, regular process of developing sports branches requires an evaluation because a program can be known to be good or bad if an evaluation of the program has been carried out. Evaluation is used as a process in determining the results that have been achieved from several planned activities. The evaluation process must be carried out comprehensively, the context and input components include document studies, namely document tracking in the form of goals and vision and mission, legal and policy foundations, athlete needs for rowing sports achievement development, program plans, athlete recruitment, coach recruitment, facilities and infrastructure support, support funding, recruitment of management, and coordination between agencies so that the results can be used as the basis for determining the quality of a program that has been implemented.

A coach will evaluate the shortcomings made by the athlete during the competition, an example of the technique carried out by the athlete. so that athletes can improve or get the best solution given by the coach. The achievements of rowing athletes from the Barito Kuala district from several numbers contested in the provincial sports week event itself are still said to be lacking when compared to other districts and cities. This can be seen from the achievements obtained by rowing athletes at the previous Provincial Sports Week event, very rarely rowers from Barito Kuala Regency who can win the canoe 
Evaluation of Rowing Sport Coaching Program in PODSI Barito Kuala Regency

Supian Hadi $^{1^{*}}$, Rahmadi ${ }^{2}$, Mashud ${ }^{3}$

supianhadi771@gmail.com

number 1 male, like 1 male and female rowing athlete Barito Kuala Regency in that number able to rank second and third.

To date Persatuan Olahraga Dayung Seluruh Indonesia (PODSI) Barito Kuala Regency can be said to be in the development stage to produce outstanding athletes. The rowing provincial championship event which was held in September 2020 yesterday which was held at Awang Regatta Banjarmasin, it became a rising point for rowing sports from Barito Kuala Regency, in that championship the rowing team from Barito Kuala Regency was ranked second.

The coaching and development system of a sports organization needs to be improved systematically and continuously so that it is in line with the goals of national development, especially in improving the welfare of all Indonesian people (Soan, 2017 p.2). In general, sports achievement development aims to advance all sports in Indonesia, each sport has a performance development program at the regional and national levels. The purpose of the achievement coaching program is to develop athletes from a young age, to find talent for athletes in each sport and to be able to achieve maximum performance as determined by the sports coach.

Based on the brief description above, the researcher will conduct research related to the evaluation of the rowing athlete coaching program at PODSI Barito Kuala Regency, which focuses on the PODSI coaching program in Barito Kuala Regency. The context and input in this study include the goals and vision and mission of PODSI Barito Kuala Regency, legal and policy foundations, athlete needs for coaching rowing sports achievement, PODSI program plan for Barito Kuala Regency, recruitment of PODSI athletes in Barito Kuala Regency, recruitment of PODSI trainers in Barito Kuala Regency, support for facilities and infrastructure, financial support, recruitment of Barito Kuala Regency PODSI management, and inter-agency coordination in the hope that it can be used as material for suggestions and input for Barito Kuala Regency PODSI management, coaches, and rowing athletes so that in the future the rowing sports branch of Barito Kuala Regency will Having good management, athletes get achievements at the regional, national and even international levels. The purpose of this study was to determine whether the coaching program at PODSI Barito Kuala Regency was effective and following what was made in the coaching program, using the Countenance Stake evaluation model approach. Determination of the effectiveness of the coaching program at PODSI Barito Kuala Regency, in terms of how much the level of achievement of the goals of the coaching program has been determined at the start of the program using the 
Countenance Stake model by evaluating each component including Antecedents, which is a condition that existed before the instructions related to the results of a program were implemented. the program of activities, for example, is the vision and mission of PODSI Barito Kuala Regency, legal and policy foundations, athlete needs for rowing sports coaching, PODSI program plan for Barito Kuala Regency, recruitment of PODSI athletes in Barito Kuala Regency, recruitment of PODSI trainers in Barito Kuala Regency, support for facilities and infrastructure, financial support, recruitment of PODSI management in Barito Kuala Regency, and coordination between agencies. The transaction is a process of instruction from a meeting that is held in the form of an activation process in the form of physical, technical, mental, tactical, tryout programs, Coach Competency Improvement programs, Competition programs, supervision and coaching of rowing sports at PODSI Barito Kuala Regency. Outcomes are effects from the experience of the coaching process, training, in the form of / output / good management, the results of the achievements achieved The results/achievements of athletes and coaches at the regional/national sports week for rowing sports, Barito Kuala district.

Theoretical benefits from the results of the evaluation of the coaching program in the rowing sport of PODSI Barito Kuala Regency are expected to be useful as a recommendation to the PODSI of Barito Kuala Regency for an evaluation facility from previous activities and be used as a reference as the preparation of a rowing sports coaching program in the future, can find out how much The advantages and disadvantages of the rowing sports coaching program at PODSI, Barito Kuala Regency. Practical benefits for coaches, athletes, rowing sports, especially canoeing numbers, and dragon boats in improving the performance of the athletes who are fostered, can find out the advantages and disadvantages of implementing the training program that has been implemented, can be used as a guide in making rowing sports training programs for improvement. the achievements of PODSI athletes in Barito Kuala Regency.

\section{METHOD}

Research Methods in research on the Evaluation of the PODSI Rowing Branch Development Program in Barito Kuala Regency using the Evaluation method with the Countenance Stake Model. The method approach in this study will reveal the extent of the coaching program in the rowing sport in Barito Kuala Regency, especially in 
Evaluation of Rowing Sport Coaching Program in PODSI Barito Kuala Regency

Supian Hadi $^{1^{*}}$, Rahmadi ${ }^{2}$, Mashud ${ }^{3}$

supianhadi771@gmail.com

planning goals and vision and mission, athlete needs, athlete recruitment, coach recruitment, facilities and funding support, implementation of training programs. The data from the evaluation of this research program will see the achievements of the coaching program at the rowing branch in the Barito Kuala district.

The qualitative research method is a research procedure that will get descriptive data results in the form of written sentences from people or individuals that can be seen. This approach leads to a person who is the sample as a whole, must not isolate someone into variables or hypotheses, but needs to see it as part of a need. Data analysis is a process of organizing and ordering data into a pattern so that themes can be found and working hypotheses can be formulated. Data analysis, in this case, includes data arrangement, data sequence, data grouping, data code and making categories from the data. Organizing data and managing data has the aim of getting themes and performance hypotheses that are eventually raised into substantive theories. Qualitative data analysis relates to data in the form of spoken words or sentences produced from the object of research and has something to do with events within the scope of the object of a study. (Siyoto, 2015 p.120).

The qualitative approach to the evaluation of the Countenance Stake research model program focuses on two main things, namely description and judgment consisting of three dimensions, namely Antecedent which is part of the context, namely the completeness of the equipment consisting of the management structure, coaching program and vision and mission, transactions which are part of the process consists of coach selection, athlete selection, training programs, facilities and infrastructure, funding, transportation, consumption, welfare and coordination and outcomes that are part of the results/achievements of athletes and coaches of regional/national sports week rowing sports, Barito Kuala Regency.

In this study, the research object selected was the Evaluation of the Coaching Program in the Rowing Sports Branch of PODSI, Barito Kuala Regency. The subject of this research is natural, as it is, without being manipulated, where the researcher does not try to manipulate the research subject. The object of this research is PODSI Barito Regency which is located at J1. Gusti Muhammad Seman RT 02 Marabahan Subdistrict, Barito Kuala Regency consists of administrators, athletes and coaches, and activities related to the evaluation of the coaching program in the management of the PODSI district of Barito Regency. The object of research consists of research variables and elements to be studied, population, sample, sample unit, research location and including 
how to draw samples. (Suryana, 2010 p. 34). So the subject of this research is a source of information that will produce data to reveal research problems. The population is the whole of the research subject (Siyoto, 2015 p. 63).

The data collection that will be used in this study is data from interviews, observation results, and documentation data about the vision and mission, recruitment of administrators, trainers, administrators, training programs, list of training activities, tryouts, funding, coordination between agencies, trainer data, training facilities and infrastructure. Sources of data in this study were informants consisting of: administrators, coaches, and rowing athletes PODSI Barito Kuala District.

In this development program evaluation research, the steps used are based on the matrix of the Countenance Stake Model, namely the description matrix and the consideration matrix, the consideration matrix can be done by researchers or evaluators after the description matrix is complete. The Description Matrix consists of planning categories and observation categories. The Consideration Matrix consists of a standard category and a consideration category. In each category, there are three focuses, namely: (1) Antecedents, namely a condition that existed before the instruction, which includes: Goals and vision and mission, Foundation, law and policy, Athletes' needs for Rowing Sports Achievement Development, Program plans, Athletes recruitment, Coach recruitment, Facilities and infrastructure support, Fund support, Management Recruitment, and Inter-Agency Coordination, (2) Transactions are meetings/activities that are carried out and are the process of instruction (activities, processes, etc.), for example: Physical, technical, mental, tactical training programs, tryout programs, Trainer Competency Improvement Programs, Competition Programs, Supervision and coaching, (3) Outcomes, namely the results of observations and achievements of athletes, for example, the results/achievements of athletes and coaches at the regional/national sports week for rowing sports, Barito Kuala Regency.

As for the three focuses, the standard category consideration matrix uses reference criteria based on the Law of the Republic of Indonesia No. 3 of 2005 concerning the National Sports System, Permenpora No. 0616 of 2014 concerning standards for managing sports organizations and the Bylaws of the All Indonesia Rowing Sports Association. ( AD/ART PB. PODSI).

The procedure used to obtain data related to the evaluation program in this study, there are several data collection techniques, including (1) The questionnaire was in the form of a questionnaire/questionnaire, used to reveal data on management, coaches, and 
athletes. The technique for filling out the questionnaire/questionnaire at the survey stage was carried out by all research subjects. The filling technique is individually and jointly guided by the researcher, this is done to reduce errors in the substance so that the correctness of the data will be obtained. (Nurdiansyah, 2016 P 4). (2) Observation is a way of collecting data by direct observation of activity. Observations can be made with photos, pictures. (3) Interview is a process of direct interaction to construct about people, events, organizations, motivations, feelings, and so on, which is carried out by two parties, namely the interviewer (interviewer) who asks questions and the interviewee (interviewee). The implementation of the interview method is a guided free interview, where the researcher is free to ask anything through direct communication. The data to be obtained from the interview method is how to evaluate the coaching program for PODSI administrators, coaches, and athletes, Barito Kuala Regency. (4) Documentation is collecting physical evidence of data regarding management decrees, training programs, activity results, competition agendas, championships participated in, organizational structures, state of coaches, athletes, and data regarding training facilities and infrastructure.

For the collection of documentation data, the researcher requested permission from the general chairman of the PODSI Regency, Barito Kuala Regency to document the training activities, training facilities and infrastructure by using documentation in the form of photos of activities. as well as physical evidence related to the training program, consisting of training cycles, management data, coaches, clubs and athlete data.

Data analysis in qualitative research is defined as an effort to systematically and carefully search and organize the records of the results of filling out questionnaires, observations, interviews, and others to increase the researcher's understanding of the problems studied and present them as findings. The data that has been collected was analyzed using qualitative descriptive data analysis. analysis of data from the results of this study was carried out based on descriptive analysis, namely an analysis described by words or sentences separated by category to obtain conclusions, the analysis consisted of three interacting analysis lines including data reduction, data presentation and conclusion drawing ( Siyoto, 2015 P.21).

Data reduction is a process of selecting, focusing on simplifying, abstracting, and transforming coarse data that emerges from field data. Data reduction needs to be done because in general, a lot of qualitative data comes from interviews and observations. Data reduction is a simplification of data so that the data can produce meaningful 
information in concluding. Data presentation is a collection of data information compiled to draw conclusions and take action. Data presentation can be in the form of narrative text, matrices, graphic designs and charts/schemas. The purpose of presenting this data is to facilitate understanding in reading and draw conclusions from a study. Concluding the collection of meanings for each category, each theme put forward in the form of narrative text which is the main core of research. The formulation of the problem that has been determined by the author will be answered after the analysis is carried out. Drawing conclusions is very useful in making a summary of the data from the final results of a study, apart from being the basis for the formulation of decision making for the researcher, it is also used as a reference for subsequent research.

\section{RESULTS AND DISCUSSION}

From the description of the results of filling out the questionnaire, it can be concluded that for the antecedent component, the results are as shown in Table 1. below:

Tabel 1.

Antecedent Voice Recapitulation

\begin{tabular}{clc}
\hline No & \multicolumn{1}{c}{ Antecedent Voice Recapitulation } & Total \\
\hline 1 & Statement instruments & 55 \\
2 & Highest score & 220 \\
3 & Lowest score & 55 \\
4 & Highest total score & 5500 \\
5 & Total score result Hasil & 4113 \\
6 & Average total score & 74,782 \\
7 & Result = average total score / 25 & 3,00 \\
8 & Criteria & Medium \\
\hline
\end{tabular}

From filling the Antecedent questionnaire, the number of statement items amounted to 55 pieces that filled out as many as 25 respondents, the total number of answers was 1375 . The results of filling out respondents who chose a good answer were 505 or equal to $36.70 \%$ of respondents chose a good answer. The results of filling out respondents who chose moderate answers were 470 or those who chose moderate answers were $34.20 \%$, respondents chose to answer enough 300 choices or $21.80 \%$, respondents chose to answer enough and respondents who chose to answer less were 100 choices or $7.27 \%$ who chose to answer Less. The percentage results from filling out the Antecedent questionnaire are as shown in the following graph: 


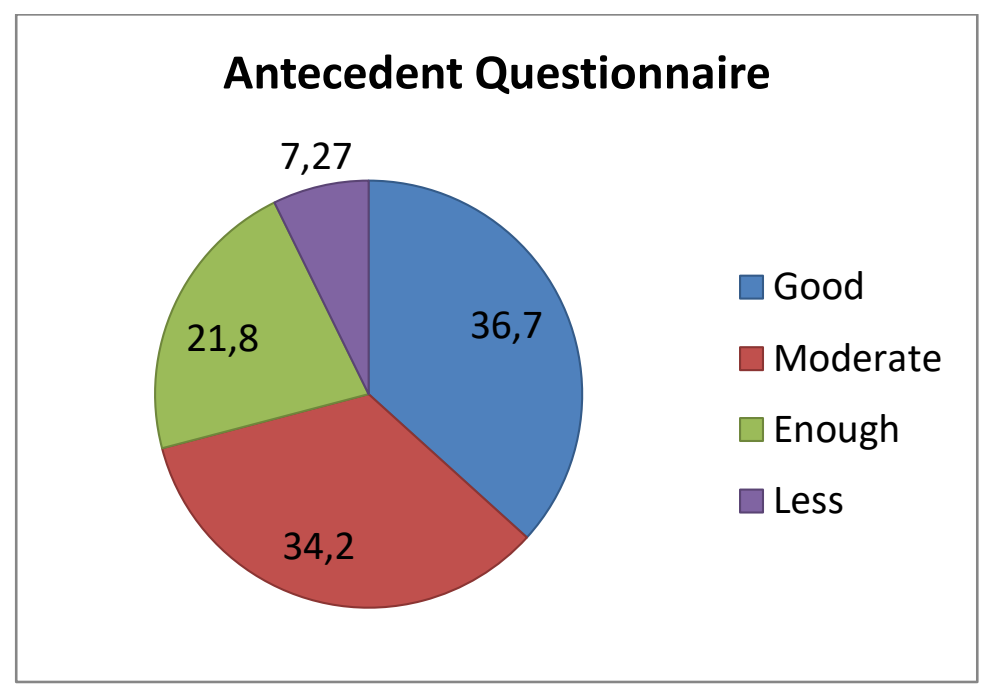

\section{Graph 1.}

Percentage of respondents in filling out the Antecedent questionnaire

Next, from the description of the results of filling out the questionnaire, it can be concluded that for the transaction component, the results are obtained as shown in Table 2. below:

Table 2.

Transaction Component Filling Recapitulation

\begin{tabular}{clc}
\hline No & Transaction Component Filling Recapitulation & Total \\
\hline 1 & Statement instruments & 26 \\
2 & Highest score & 104 \\
3 & Lowest score & 26 \\
4 & Highest total score & 2600 \\
5 & Total score result Hasil & 1998 \\
6 & Average total score & 76,846 \\
7 & Result = average total score / 25 & 3,04 \\
8 & Criteria & Medium \\
\hline
\end{tabular}

The results of filling out the Outcome questionnaire, the number of statement items amounted to 26 pieces that filled out as many as 25 respondents, the total number of answers was 650 . The results of filling out respondents who chose a good answer were 252 or equal to $38.77 \%$ of respondents who chose a good answer. The results of filling out respondents who chose moderate answers were 231 or those who chose moderate answers were $35.54 \%$, respondents chose to answer enough 133 or $20.46 \%$, respondents chose to answer enough and respondents who chose less answered 34 choices or 5, 23\% who chose to answer Less The percentage results from filling out the Transaction questionnaire are as shown in the following graph: 


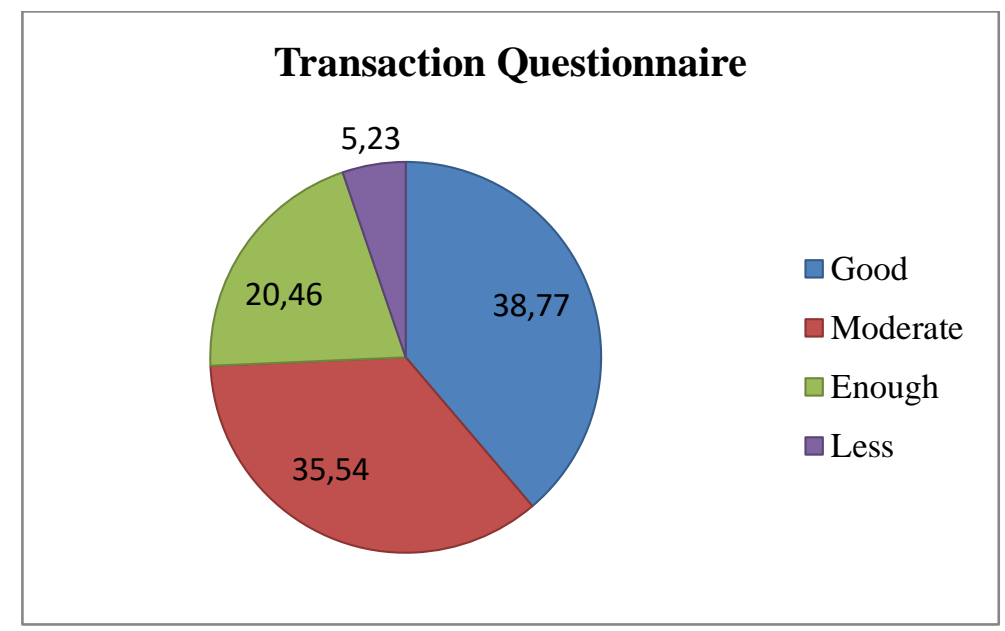

Graph 2.

Percentage of respondents in filling out the Transaction questionnaire

Next, from the description of the results of filling out the questionnaire, it can be concluded that for the Outcome component, the results are as shown in Table 3. below:

Tabel 3.

Recapitulation of Outcome Component Contents

\begin{tabular}{clc}
\hline No & Recapitulation of Outcome Component Contents & Total \\
\hline 1 & Statement instruments & 6 \\
2 & Highest score & 24 \\
3 & Lowest score & 6 \\
4 & Highest total score & 600 \\
5 & Total score result Hasil & 452 \\
6 & Average total score & 75,33 \\
7 & Result = average total score / 25 & 3,01 \\
8 & Criteria & Medium \\
\hline
\end{tabular}

The results of filling out the Outcome questionnaire, the number of statement items amounted to 6 pieces that filled out as many as 25 respondents, the total number of answers was 150. The results of filling out respondents who chose good answers were 58 or equal to $38.67 \%$ of respondents who chose good answers. The results of filling out respondents who chose moderate answers were 54 or those who chose moderate answers were $36.00 \%$, respondents chose to answer enough 20 choices or $13.33 \%$, respondents chose to answer enough and respondents who chose less answered 18 choices or $12.00 \%$ who chose to answer Less The percentage results from filling out the Outcome questionnaire are as shown in the following graph: 


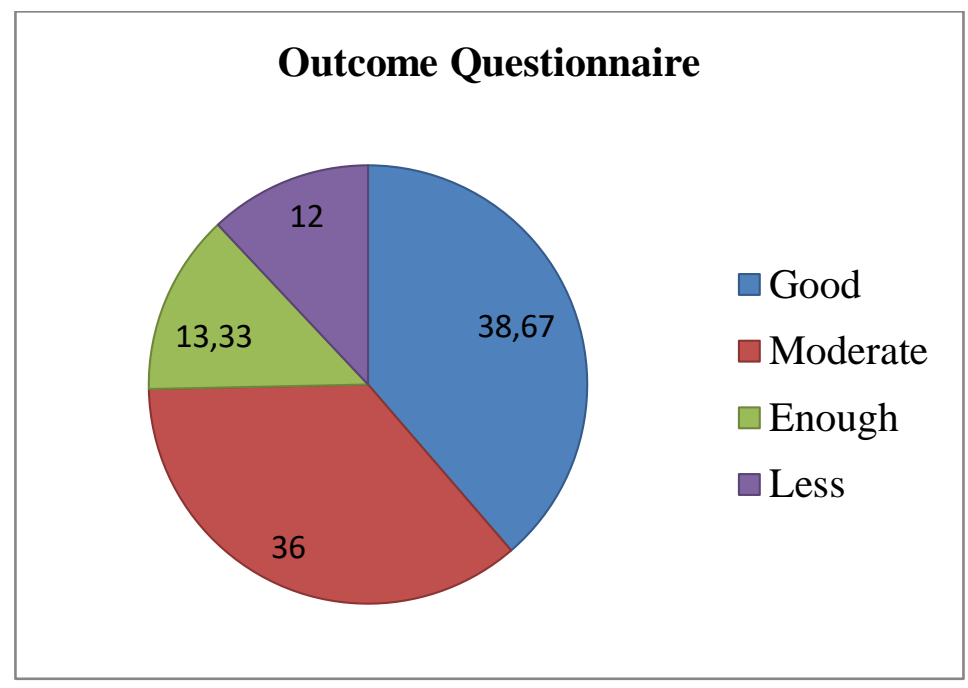

\section{Graph 3.}

Percentage of respondents in filling out the Outcome questionnaire

A more detailed discussion on each indicator to determine the achievement of the management implementation of the PODSI rowing sport in Barito Kuala Regency. These indicators include the objectives and vision and mission of PODSI Barito Kuala Regency which shows that the quality is generally moderate, but there are still some indicators that still need to be improved, such as administrators, coaches, and athletes having a good understanding of the PODSI vision and mission of Barito Kuala Regency. organizational components know and implement programs following the vision and mission, recruitment of trainers based on licenses and levels of education, in addition to the fulfilment of professional physical trainers need to be done to support the achievement of the athlete's performance being fostered. The need for a qualified coach in coaching rowing sports achievement. The good physical condition will greatly affect the performance of athletes both during training and competing. Research data shows that the implementation of coach recruitment is still moderate. The absence of a coach promotion and relegation system will cause a lack of motivation for coaches to improve their coaching performance. The existence of a promotion and relegation system in the process of coaching rowing performance needs to be implemented to stimulate the spirit of the coach to develop and maximize his training performance. Athlete Recruitment shows that the quality of athletes is in the moderate category. The implementation of the exercise is good with the try out for athletes and the schedule of matches that are followed by athletes. Several indicators on the quality of athletes need to be improved to maximize athlete performance. The selection of athletes that have been carried out so far is still using a natural approach, the development and progress of athletes are very slow. 
Therefore, the implementation of the selection of junior rowing athletes based on body posture, physical condition, technical skills and academic tests will be able to help administrators and coaches to attract talented athletes in the rowing sport so that the achievement of training results will be maximized if the athletes who are netted talented in the sport of rowing. Optimal achievement must be accompanied by the implementation of a systematic, planned, and sustainable coaching and development process supported by sports science and technology. Therefore, improvement and maximization of the management of the PODSI trainers and rowing athletes in Barito Kuala Regency need to be carried out to optimize achievement.

Summary The discussion of the results of the interview is as follows: PODSI Barito Kuala Regency has carried out coaching since 1987, the organization has a management with a 5-year term of service, in collaboration with KONI and Regency Dispora in terms of funding, in collaboration with Provincial Dispora and Kemenpora in the form of PPLP and PPLPD, does not yet have trainers who are following the rowing coaching license, do not yet have referees, both regional licenses and national licenses, own facilities but are still lacking, the need for a special rowing canal so that it becomes a restorative medium for athlete training and the implementation of championships at the regional and national levels in Barito Regency Kuala.

Summary Discussion of the results of the observations and documentation are as follows. The management of the PODSI rowing sport in Barito Kuala Regency, in general, has carried out their respective duties and functions, the trainer's ability to manage training activities is quite good, the coach has made an exercise program, training schedule and there is a schedule physical and technical training as a result of the implementation of this training program is proven by various achievements. It is necessary to improve the quality of the coach, following the training of special trainers according to the sport. It is necessary to increase the capacity of refereeing because the PODSI of Barito Kuala Regency holds a championship every year. There is a need to improve rowing facilities and infrastructure that are more representative to support athletes' training during this time athletes practice.

Analysis of research data based on the countenance stake evaluation model on the antecedent, transaction and outcome components as shown in the following Table 4: 
Table 4.

The results of the study of the Countenance Stake evaluation model on the antecedent, transaction and outcome components

\begin{tabular}{|c|c|c|c|c|}
\hline \multicolumn{2}{|c|}{ Matrix Description } & \multirow{2}{*}{$\begin{array}{c}\text { Antace } \\
\text { den }\end{array}$} & \multicolumn{2}{|c|}{ Consideration Matrix } \\
\hline Intense & Observation & & Standard & Consideration \\
\hline $\begin{array}{l}\text { Objectives, } \\
\text { vision and } \\
\text { mission, } \\
\text { Foundation } \\
\text {, law and } \\
\text { policy, } \\
\text { Athletes' } \\
\text { needs for } \\
\text { Rowing } \\
\text { Sports } \\
\text { Achieveme } \\
\text { nt } \\
\text { Developme } \\
\text { nt, Athlete } \\
\text { Recruitmen } \\
\text { t Program } \\
\text { Plans, } \\
\text { Recruitmen } \\
\text { t of } \\
\text { coaches, } \\
\text { administrat } \\
\text { ors, Fund } \\
\text { support for } \\
\text { inter- } \\
\text { agency } \\
\text { coordinatio } \\
\text { n }\end{array}$ & $\begin{array}{l}\text { There is a description of } \\
\text { the vision and mission } \\
\text { and it is placed on the } \\
\text { secretariat wall, There } \\
\text { is a legal basis and the } \\
\text { PODSI Management } \\
\text { Decree in the Barito } \\
\text { Kuala district, the } \\
\text { management of } \\
\text { achievement } \\
\text { development activities } \\
\text { is still not up to } \\
\text { standard, the training } \\
\text { program is only a short- } \\
\text { term program to } \\
\text { participate in a } \\
\text { competition event, the } \\
\text { coach does not have } \\
\text { know There is no } \\
\text { adequate program } \\
\text { regarding the training } \\
\text { program, there is no } \\
\text { PODSI program for } \\
\text { Barito Kuala Regency } \\
\text { for the medium and } \\
\text { long term } \\
\text { The recruitment of } \\
\text { athletes has not set the } \\
\text { appropriate criteria, } \\
\text { there has been no } \\
\text { selection held by } \\
\text { screening through talent } \\
\text { scouting } \\
\text { Coach recruitment is } \\
\text { carried out based on } \\
\text { experience as a rowing } \\
\text { athlete, so coaches are } \\
\text { recruited from former } \\
\text { rowing athletes }\end{array}$ & & $\begin{array}{l}\text { The organization must } \\
\text { establish a vision and } \\
\text { mission for a certain } \\
\text { time and it is stated in } \\
\text { the articles of } \\
\text { association and spelt } \\
\text { out in the work program } \\
\text { Organizations must be } \\
\text { created based on } \\
\text { applicable laws } \\
\text { Organizations must } \\
\text { have program policies, } \\
\text { procedures, curriculum } \\
\text { syllabus for } \\
\text { implementation } \\
\text { Organizations must } \\
\text { have program policies, } \\
\text { procedures, curriculum } \\
\text { syllabus for } \\
\text { implementation } \\
\text { The organization sets } \\
\text { standards and } \\
\text { coordinates the } \\
\text { implementation of } \\
\text { nursery patterns, } \\
\text { starting with high- } \\
\text { quality seeds in schools, } \\
\text { as well as canoeing and } \\
\text { dragon boat rowing } \\
\text { sports clubs; } \\
\text { Organizations should } \\
\text { have guidelines for the } \\
\text { selection of athletes } \\
\text { according to their level } \\
\text { Training and Coaching } \\
\text { for regional, national, } \\
\text { international level } \\
\text { trainers } \\
\text { (Permenpora No 0616 } \\
\text { of } 2014 \text { ) }\end{array}$ & $\begin{array}{l}\text { Need for Adjustment The } \\
\text { making of the vision and } \\
\text { mission should pay } \\
\text { attention to the vision and } \\
\text { mission of PB PODSI, } \\
\text { Provincial PODSI as well } \\
\text { as the vision and mission } \\
\text { of the local government in } \\
\text { the field of sports, It is } \\
\text { necessary to adjust } \\
\text { personnel in the } \\
\text { management decree that } \\
\text { leads to the management } \\
\text { structure sourced from PB } \\
\text { PODSI, in carrying out } \\
\text { workshop activities for } \\
\text { administrators and trainers } \\
\text { in in terms of improving } \\
\text { medium and long-term } \\
\text { coaching programs, in } \\
\text { conducting workshops for } \\
\text { administrators and trainers } \\
\text { in terms of improving } \\
\text { medium and long-term } \\
\text { coaching programs that are } \\
\text { in line with the programs } \\
\text { of the PB and PODSI } \\
\text { Province, in terms of the } \\
\text { recruitment of athletes } \\
\text { should pay attention to } \\
\text { health, biometric quality, } \\
\text { heredity, facilities, climate } \\
\text { and experts Need } \\
\text { Adjustments Because the } \\
\text { trainers are former athletes, } \\
\text { the next step taken by } \\
\text { PODSI Barito Kuala } \\
\text { Regency is to provide } \\
\text { opportunities for coaches } \\
\text { to participate in capacity } \\
\text { building activities as } \\
\text { coaches through trainer } \\
\text { training. }\end{array}$ \\
\hline $\begin{array}{l}\text { Physical, } \\
\text { technical, } \\
\text { mental, } \\
\text { tactical } \\
\text { training } \\
\text { programs, } \\
\text { tryout } \\
\text { programs, } \\
\text { Coach } \\
\text { Competenc }\end{array}$ & $\begin{array}{l}\text { The training program } \\
\text { carried out has a } \\
\text { schedule, cycle, and } \\
\text { material provided, but } \\
\text { the program is } \\
\text { constrained by weather } \\
\text { conditions and the } \\
\text { situation on the Barito } \\
\text { River, so that there are } \\
\text { training materials that }\end{array}$ & on & $\begin{array}{l}\text { The role of coaches in } \\
\text { coaching athlete } \\
\text { achievement is very } \\
\text { vital. Good and bad } \\
\text { athlete achievement } \\
\text { depends on the way the } \\
\text { coach plans and } \\
\text { implements the correct } \\
\text { and appropriate } \\
\text { training. This is because }\end{array}$ & $\begin{array}{l}\text { Needs Adjustments To } \\
\text { overcome bad weather } \\
\text { conditions on the river, } \\
\text { there should be facilities } \\
\text { that can be done to fulfill } \\
\text { the training load with ergo } \\
\text { anoeing. } \\
\text { Need for Adjustments } \\
\text { Incorporating the try out } \\
\text { program into the annual }\end{array}$ \\
\hline
\end{tabular}




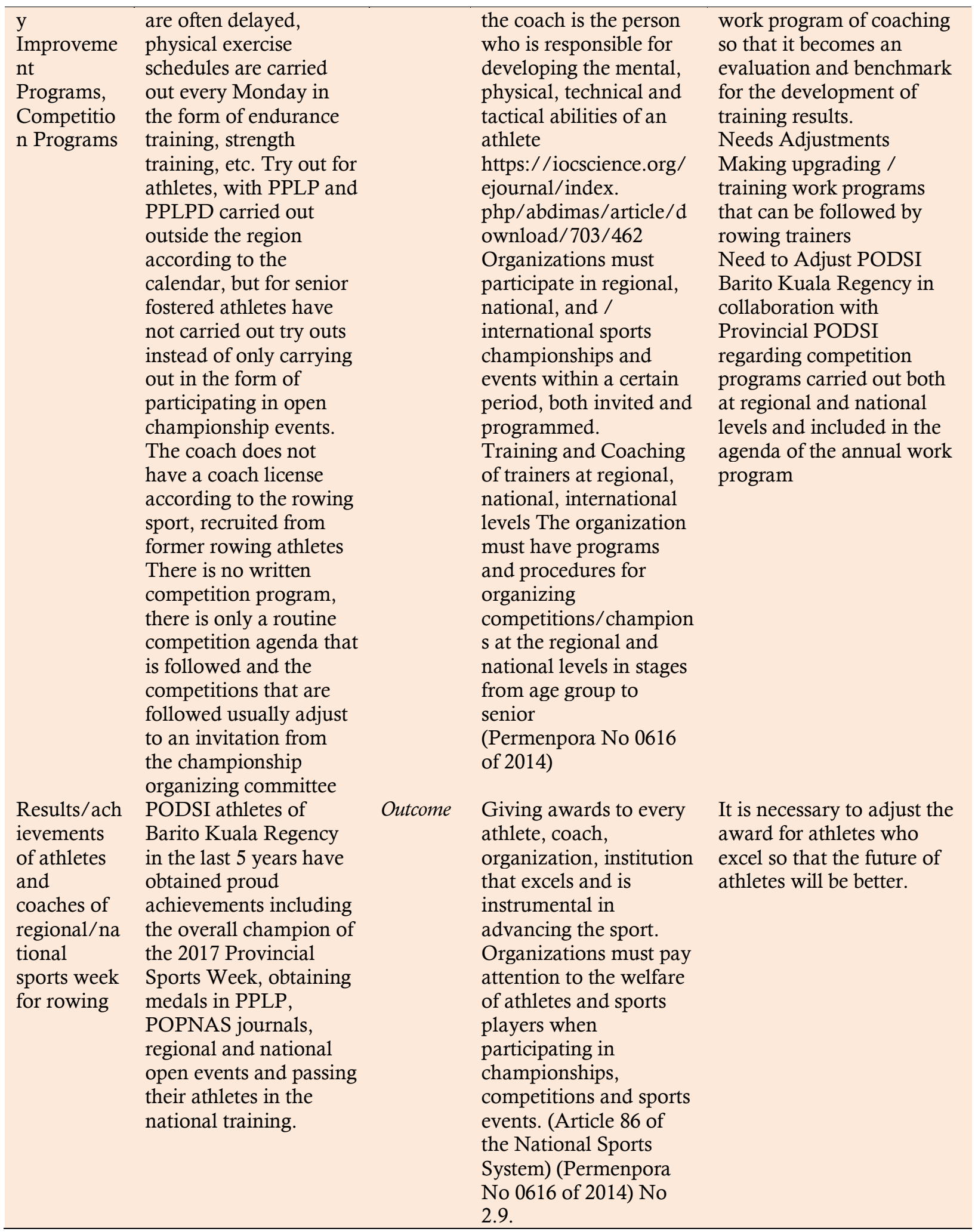

Recommendations based on research results based on program research results need to pay attention to increasing the capacity of coaches, referees and improving facilities, infrastructure and special rowing canals so that they become a restorative medium for athlete training and the implementation of rowing championships in Barito 
Evaluation of Rowing Sport Coaching Program in PODSI Barito Kuala Regency

Supian Hadi $^{1^{*}}$, Rahmadi ${ }^{2}$, Mashud ${ }^{3}$

supianhadi771@gmail.com

Kuala Regency. The coaching of sports organizations and the parent of rowing sports in Barito Kuala Regency can be done through regular education channels in schools and non-regular in the form of rowing clubs, where the foundation is laid for early and sustainable youth and sports development because it is essentially an asset in building the nation. As a form of struggle to form the character and glue of national unity and integrity. The development of sports organizations and the parent of rowing sports in Barito Kuala Regency needs to be adapted to technological developments and advances. The ideal is that the increase in achievement should be supported by the success of increasing sports nurseries early and evenly throughout the community. In terms of coaching in the PODSI rowing sport, Barito Kuala District, three categories of human resources for sports personnel (coaches, PJOK teachers and sports instructors) have an important role in coaching with good coordination through physical education teachers who can convey information on the existence of the PODSI parent organization so that children can channel their talents in branches, through coaches in rowing sports children can be directed how to practice sports which can improve their achievements both at the student level and at a higher level, in terms of sports instructors in this case in Barito Kuala district as far as researchers know there are no instructors It is hoped that in the future Barito Kuala Regency will have a sports instructor.

\section{CONCLUSIONS AND SUGGESTIONS}

The results of the study by evaluating the Contenance Stake model from filling in the questionnaire showed that the antecedent component was in the medium category, the transaction component was in the medium category, and the outcome component was in the medium category, the results of interviews, observations and documentation of PODSI Barito Kuala Regency, in collaboration with the Provincial Dispora and the Ministry of Youth and Sports in the form of PPLP and PPLPD does not yet have a licensed trainer for rowing training, does not yet have a licensed referee, and the facilities are still inadequate.

Based on the research results, the implications both theoretically and practically can be described, namely: Theoretical Implications The selection of the Countenance Stake program evaluation model consisting of three components, namely antecedent, transaction and outcome by comparing the description matrix consisting of an intense matrix and a description matrix with a consideration matrix consisting of a standard 
Evaluation of Rowing Sport Coaching Program in PODSI Barito Kuala Regency

Supian Hadi $^{1^{*}}$, Rahmadi ${ }^{2}$, Mashud ${ }^{3}$

supianhadi771@gmail.com

matrix and a consideration matrix. From the results of observational analysis of antecedent data, transactions and outcomes in the field, they are compared with the standard matrix, after which it can only be continued to the consideration matrix and can then provide recommendations from the Countenance stake evaluation that distinguishes it from other evaluation models; Practical Implications The results of the evaluation of the coaching program at the PODSI rowing sport in Barito Kuala Regency are used as input for the Management, in making organizational improvements; Rowing is a sports organization that can serve as an example for other sports in the Barito Kuala district. For future coaches, they can take part in trainer training activities so that things related to the training program can increase their knowledge for rowing athlete training activities in Barito Kuala district and can improve the performance of rowing athletes in Bario Kuala district in sports week events and upcoming championships.

Based on the results of the study, the evaluation of the PODSI Rowing Sports Branch Development Program in Barito Kuala Regency in Marabahan can be put forward the following suggestions: The PODSI management of Barito Kuala Regency plays a role in disseminating the Vision and Mission Goals to all members of the Community, Athletes so that a good understanding of the concept of Vision and Mission Objectives will be formed and run smoothly during the implementation of the coaching program in the field; PODSI management in Barito Kuala Regency in carrying out the coaching program, improving the recruitment administration mechanism both online and offline for administrators, coaches, and athletes according to the PODSI AD/ART, so that there is clear written documentation regarding the recruitment of administrators, coaches and athletes that has been carried out by PODSI Barito Kuala district; The management of PODSI in Barito Kuala Regency in carrying out the coaching program, increasing resources in the field of achievement coaching and refereeing so that it can support the achievements of athletes and the rowing competition agenda in Barito Kuala Regency can be included in the PB PODSI agenda; The management of PODSI in Barito Kuala Regency in carrying out coaching programs, improving rowing facilities and infrastructure, so that with these facilities and infrastructure can improve athlete achievement and also have an impact on the economy of the people of Barito Kuala Regency; and the Barito Kuala District PODSI management, which carries out the coaching program, has further improved the documentation administration mechanism regarding athlete achievements from year to year which has been carried out by the Barito Kuala District PODSI so that it is easily accessible directly. 


\section{REFERENCES}

Ananda, R., \& Rafida, T. (2017). Pengantar Evaluasi Program pendidikan. In Medan: Perdana Publishing (Vol. 53, Issue 9). https://doi.org/10.1017/CBO9781107415324.004

Arifin, Z. (2010). Model-model evaluasi program. 14. Jurusan Kurikulum Dan Teknologi Pendidikan Fakultas Ilmu Pendidikan Universitas Pendidikan Indonesia Bandung.

Dermawan, D. F., \& Karawang, U. S. (2018). Perencanaan Latihan (Periodisasi) Perencanaan Latihan (Periodisasi) https://www.researchgate.net/profile/Dikdik Dermawan/publication/328731 s

Irfandi. (2017). Manajemen Penjas dan Olahraga. https://repository.bbg.ac.id/bitstream/453/1/Manajemen Penjas dan Olahraga. pdf

Jaedun, A. (2010). Metode Penelitian Evaluasi Program. Pelatihan Metode Penelitian Evaluasi Kebijakan Dan Evaluasi Program Pendidikan, 1-14. http://staffnew.uny.ac.id/upload/131569339/pengabdian/penelitian-evaluasiprogram.pdf

Jamalong, A. (2014). Peningkatan Prestasi Olahraga Nasional Secara Dini Melalui Pusat Pembinaan Dan Latihan Pelajar (PPLP) Dan Pusat Pembinaan Dan Latihan Mahasiswa (PPLM). Jurnal Pendidikan Olahraga, 3(2), 156-168. https://doi.org/http://dx.doi.org/10.31571/jpo.v3i2.127

Kantun, S. (2012). Penelitian Evaluatif Sebagai Salah Satu Model Penelitian Dalam Bidang Pendidikan. Majalah Ilmiah Dinamika, 37(1), 15.

Khodari, R. (2017). Evaluasi Program Pendidikan Kelas Khusus Olahraga Sekolah Menengah Atas Negeri 1 Sewon Bantul Yogyakarta. Multilateral Jurnal Pendidikan Jasmani Dan Olahraga, 15(2), 124-132. https://doi.org/10.20527/multilateral.v15i2.2740

Mahmudi, I. (2011). CIPP: Suatu Model Evaluasi Program Pendidikan. Jurnal AtTa'dib, 6(1), 118.

Mansur. (1994). Pemilihan Bibit Unggul Dalam Pelatihan Olahraga. Cakrawala Pendidlikan, 87-96.

Munthe, A. P. (2015). Pentingya Evaluasi Program Di Institusi Pendidikan: Sebuah Pengantar, Pengertian, Tujuan dan Manfaat. Scholaria: Jurnal Pendidikan Dan Kebudayaan, 5(2), 1. https://doi.org/10.24246/j.scholaria.2015.v5.i2.p1-14

Muttaqin, M. S. (2016). Evaluasi Program Pembinaan Sepak Bola Pada Persatuan Sepak Bola Brebes Universitas Negeri Semarang http://lib.unnes.ac.id/26477/

Nurdiansyah. (2016). Evaluasi Pembinaan Olahraga Renang Di Provinsi Kalimantan Selatan Banjarmasin. Jurnal Multilateral, volume 13(1), 150-165. 
Nurjaya. (2009). Tahapan pembinaan atlet jangka panjang, Penataran pelatih PPLM (Pusat Pembinaan dan Latihan Olahraga Mahasiswa) dan Perguruan Tinggi SeIndonesia, Surabaya 24-27 Mei 2009.

Nurjaya, D. R. (2012). Tahapan pembinaan atlet dayung jangka panjang. Jurnal Kepelatihan Olahraga, 4(2), 108-123.

Oemar, Triyono Masyhury. (2018). Evaluasi Program Latihan Atlet Puslatda Cabang Olahraga Renang NTB https://jurnalmahasiswa.unesa.ac.id/index.php/jurnalprestasi-olahraga/article/view/27284

Siyoto, Sandu. (2015). Dasar Metodologi Penelitian (Cetakan 1,). http://bppsdmk.kemkes.go.id/pusdiksdmk/wpcontent/uploads/2017/11/Metodo logi-Penelitian-dan-Statistik-SC.pdf

Suryana, (2010). Metodologi Penelitian: Metodologi Penelitian Model Prakatis Penelitian Kuantitatif dan Kualitatif. Universitas Pendidikan Indonesia, 1-243. https://doi.org/10.1007/s13398-014-0173-7.2

PU, D. (2016). Review Penyusunan RPI2JM Bidang Kecipta Karyaan 2017-2022. In Marabahan.

Sari, H. P. (2017). Evaluasi Program Pembinaan Atlet Pekan Olahraga Nasional Cabang Olahraga Bulu Tangkis Provinsi Sumatera Selatan. Journal of Physical Education and Sports, 6(3), 261-265.

Setiadin, G. A. (2019). PENGPROV PODSI JATIM Gigih Arif Setiadin Abstrak. 1-8. https://jurnalmahasiswa.unesa.ac.id/index.php/jurnal-prestasiolahraga/article/view/32194

Soan, U. F. (2017). Kebijakan Dan Strategi Pembinaan Olahraga Prestasi Daerah. Jurnal Sains Keolahragaan Dan Kesehatan, 20. https://doi.org/10.5614/jskk.2017.2.1.5

Sumaryanto. (2005). Sport Development Index Sebagai Parameter. 1-11.

UU No 3 Tahun 2005. (2005). Undang-Undang Republik Indonesia Nomor 3 Tahun 2005 Tentang Sistem Keolahragaan Nasional Dengan. Presiden RI, 1, 1-53.

Wahyudhiana, D. dan. (2015). Model Evaluasi Program Pendidikan. Islamadina, XIV NO 1.

http://jurnalnasional.ump.ac.id/index.php/ISLAMADINA/article/view/1665

Wani1, B. (2018). Evaluasi Program Pembinaan Prestasi Cabang Olahraga Tinju Pada Pusat Pembinaan Dan Latihan Olahraga Pelajar (Pplp) Provinsinusa Tenggara Timur. Jurnal Ilmiah Pendidikan Citra Bakti, 5(1), 35-43. http://www.ejournal.citrabakti.ac.id/index.php/jipcb/article/view/138 
Wibowo, T. P. (2017). Evaluation Teaching Physical Education 2015/2016 in Junior High School Bengkulu Selatan. Multilateral Jurnal Pendidikan Jasmani Dan Olahraga, 15(2), 111-124. https://doi.org/10.20527/multilateral.v15i2.2738

Yasin, Syahid Nur (2014). Jurnal Olahraga Pendidikan. Jurnal Olahraga Pendidikan, $1(1), 91$.

Zainuddin, M. (2016). Evaluasi Penerapan Program Pembinaan DAYUNG. http://lib.unnes.ac.id/27297/

Zulmi, Nizar (2012). Survey Pembinaan olahraga dayung di jawa tengah. Active Journal of Physical Education, Sport, Health and Recreation, 1(3). https://doi.org/10.15294/active.v1i3.446 